\title{
Gambaran nyeri kepala pada mahasiswa pemain game komputer di Fakultas Kedokteran Universitas Sam Ratulangi angkatan 2012
}

\author{
${ }^{1}$ Andre A. Rori \\ ${ }^{2}$ Melke J. Tumboimbela \\ ${ }^{2}$ Mieke A. H. N. Kembuan \\ ${ }^{1}$ Kandidat Skripsi Fakultas Kedokteran Universitas Sam Ratulangi manado \\ ${ }^{2}$ Bagian/SMF Neurologi RSUP Prof. Dr. R. D. Kandou Manado \\ Email: andrealexanderrori@gmail.com
}

\begin{abstract}
Headache or cephalalgia is a sensation of pain on the head to neck. Headache is divided into primary headache disorders and secondary headache disorders. Playing computer games is one of the university students' usual activities. However, it can be a risk factor contributor for both types of headache. This study aimed to obtain the headache patterns and representations among university students who played computer games. This was a descriptive study with a cross-sectional design using questionairre . The sampling technique used was non-probability sampling with $\mathrm{N}=50$. Data were analyzed by using frequency tables and cross tabulations. The results showed that there were 44 university students (88\%) experienced headache while playing or at the moment after playing computer game. Mild pain level was the most experienced symptom, as many as 28 university students (56\%). The patterns and other headache symptoms were categorized in tension-type (60\%), migraine (28\%), and no headache (12\%).
\end{abstract}

Keywords: headache, computer gamer, university student.

\begin{abstract}
Abstrak: Nyeri kepala atau cephalalgia adalah sensasi nyeri di bagian kepala hingga batas leher. Nyeri kepala terbagi atas nyeri kepala primer dan nyeri kepala sekunder. Bermain game komputer merupakan salah satu aktivitas yang sering dilakukan mahasiswa dan dapat menjadi kontributor faktor risiko terjadinya kedua tipe nyeri kepala tersebut. Penelitian ini bertujuan untuk mengetahui gambaran nyeri kepala pada mahasiswa pemain game komputer. Jenis penelitian ini ialah deskriptif dengan desain potong lintang menggunakan kuesioner. Teknik sampling yang digunakan ialah non-probability sampling yaitu consecutive sampling dengan $\mathrm{N}=50$. Data dianalisis menggunakan tabel frekuensi dan cross tabulation. Hasil penelitian memperlihatkan 44 mahasiswa (88\%) mengalami nyeri kepala selama atau sesaat setelah bermain game komputer. Derajat nyeri ringan merupakan yang paling banyak dialami, yaitu dialami oleh 28 mahasiswa (56\%). Gambaran dan gejala nyeri kepala lainnya dikelompokkan dan mengarah ke nyeri kepala tipe tensi sebanyak $60 \%$, tipe migraine $28 \%$, dan sisanya $12 \%$ tidak nyeri kepala
\end{abstract}

Kata kunci: nyeri kepala, pemain game komputer, mahasiswa

Nyeri kepala atau cephalalgia adalah sensasi nyeri di bagian kepala hingga batas leher. Nyeri kepala merupakan salah satu keluhan paling sering muncul pada pasien yang ingin berobat. Nyeri kepala sesuai dengan International Headache Society terbagi atas nyeri kepala primer dan sekunder. ${ }^{1}$

Nyeri kepala primer adalah sakit kepala yang disebabkan oleh gangguan pada struktur di kepala yang sensitif terhadap rasa sakit dan bukan merupakan gejala akibat penyakit lain, sedangkan nyeri kepala sekunder disebabkan oleh penyakit 
lain. Dari hasil penelitian di Singapura didapati prevalensi nyeri kepala sebesar 82,7\%. Penelitian internasional menemukan prevalensi nyeri kepala pada anak-anak dan remaja terus meningkat. Selain itu, diperkirakan nyeri kepala menetap pada saat usia dewasa dalam persentase yang relatif tinggi (sekitar 50\%) dari kasus. ${ }^{2}$

Nyeri kepala primer dibagi menjadi beberapa tipe dan sesuai dengan angka kejadiannya secara global menjadi tensiontype $69 \%$, migren $16 \%$, stabbing idiopatik $2 \%$, exertional $1 \%$, cluster $0.1 \%$, tipe-tipe yang lain $11 \%{ }^{1}$

Secara fisik, nyeri kepala primer tipe tegang otot dapat disebabkan oleh posisi kepala yang menetap terlalu lama. Sedangkan secara psikis, stres maupun konflik emosional dapat menyebabkan nyeri kepala tipe tegang otot. Pada nyeri kepala migren, diketahui pemaparan cahaya fluorescent menjadi faktor risiko terjadinya nyeri kepala ini. Semua faktor risiko yang disebutkan tadi dapat diakibatkan dari bermain game komputer. Walaupun game komputer sering dijadikan sarana rekreasi, game komputer juga dapat menyebabkan stress. ${ }^{3}$ Menurut penelitian yang dilakukan pada 400 pelajar dalam kelompok usia 1019 tahun didapat bahwa remaja menghabiskan lebih banyak waktu bermain game dan menonton televisi. ${ }^{4,5}$

Pada hasil penelitian yang dilakukan Torsheim dkk di Denmark, Finlandia, Islandia, Norwegia, dan Swedia, ditemukan 23,3\% anak laki-laki mengalami nyeri kepala rekuren berhubungan dengan penggunaan media elektronik dan 34,8\% pada anak perempuan. Penelitian di Finlandia pada 7292 peserta menunjukkan bahwa anak laki-laki lebih sering bermain game digital dan menggunakan internet dibandingkan anak perempuan yang lebih sering menggunakan handphone. ${ }^{6}$

Penelitian yang dilakukan pada 1025 remaja di Jerman ditemukan sebagian besar remaja menggunakan komputer (85\%), menonton televisi (90\%) atau mendengarkan musik (90\%), hanya 23\% partisipan yang menggunakan handphone dan $25 \%$ bermain game setiap hari. ${ }^{7}$
Menurut National Institute of Occupational Safety and Health, 90\% orang-orang yang menghabiskan waktu 3 jam atau lebih memakai komputer mengalami nyeri kepala, nyeri punggung bawah, dan mata lelah. Studi lain di Malaysia pada 795 mahasiswa umur 18-25 tahun didapatkan nyeri kepala, mata lelah, serta nyeri punggung bawah dengan persentasi $89,9 \%{ }^{8}$

Di Indonesia sendiri pernah dilakukan penelititan di Medan pada 100 orang usia 18-21 tahun didapatkan semuanya mengalami nyeri kepala primer dan uji korelasi menunjukkan terdapat hubungan antara penggunaan media elektronik dengan nyeri kepala yaitu nilai $\mathrm{p}<0,05{ }^{9}$

Tujuan dilakukannya penelitian ini adalah untuk mengetahui gambaran nyeri kepala pada mahasiswa yang bermain game komputer di Fakultas Kedokteran Universitas Sam Ratulangi angkatan 2012. Dengan mengetahui gambaran nyeri kepala tersebut, diharapkan dapat menambah wawasan, pengetahuan, dan keterampilan mengenai nyeri kepala pada orang-orang yang bermain game komputer.

\section{METODE PENELITIAN}

Jenis penelitian ini deskriptif dengan desain potong lintang. Lokasi penelitian ini dilakukan di kampus Fakultas Kedokteran Universitas Sam Ratulangi Manado dan posko-posko di Kabupaten Minahasa tempat mahasiswa melaksanakan KKT. Populasi penelitian ini ialah mahasiswa Fakultas Kedokteran Universitas Sam Ratulangi Manado angkatan 2012 yang sesuai dengan kriteria inklusi dan kriteria eksklusi. Kuesioner digunakan untuk memperoleh data gambaran nyeri kepala pada mahasiswa pemain game komputer di Fakultas Kedokteran Universitas Sam Ratulangi angkatan 2012.

Variabel penelitian yaitu: Jenis kelamin, usia, durasi bermain game computer, saat biasa bermain game computer, dan nyeri kepala.

Responden yang memenuhi kriteria inklusi dan eksklusi diberikan kuesioner penelitian. Data dari responden dioleh 
dengan program SPSS, Microsoft Excel, dan Microsoft Word.

\section{HASIL PENELITIAN}

Berdasarkan Tabel 1 didapatkan kelompok usia mahasiswa yang terbesar ialah 21 tahun yaitu 58\% (29 orang), sisanya sebesar 34\% (17 orang) berusia 20 tahun, 4\% (2 orang) berusia 19 tahun, dan $4 \%$ (2 orang) berusia 22 tahun. Jenis kelamin yang paling banyak ialah laki-laki 82\% (41 orang) kemudian perempuan 18\% (9 orang).

Tabel 2 menunjukkan 88\% responden (44 orang) mengalami nyeri kepala selama atau sesaat setelah bermain game komputer dan sisanya $12 \% \quad$ (6 orang) tidak mengalami nyeri kepala.

Berdasarkan durasi bermain game komputer, pada 3-4 jam, gejala yang mengarah ke nyeri kepala tipe tensi adalah 15 orang dan migraine 9 orang dari total 28 orang. Pada $>6$ jam, 5 orang memiliki gejala yang mengarah ke nyeri kepala tipe tensi dan migraine 4 orang dari total 10 orang. Kemudian pada 5-6 jam tidak ada yang mengalami gejala yang mengarah ke nyeri kepala tipe migraine, sisanya tipe tensi 8 orang dan yang tidak mengalami nyeri kepala 1 orang dari total 9 orang. Pada 4-5 jam, 2 orang gejalanya mengarah ke tipe tensi dan sisanya 1 orang mengarah ke tipe migraine.

Tabel 1. Karakteristik dan persentase responden menurut usia dan jenis kelamin

\begin{tabular}{|c|c|c|c|c|}
\hline & & \multicolumn{2}{|c|}{ Jenis Kelamin } & \multirow{2}{*}{ Total } \\
\hline & & Laki-laki & Perempuan & \\
\hline \multirow{4}{*}{ Usia } & 19 thn & 2 & 0 & $2(4 \%)$ \\
\hline & 20 thn & 13 & 4 & 17 (34\%) \\
\hline & 21 thn & 24 & 5 & 29 (58\%) \\
\hline & 22 thn & 2 & 0 & $2(4 \%)$ \\
\hline \multicolumn{2}{|c|}{ Total } & $41(82 \%)$ & $9(18 \%)$ & 50 (100\%) \\
\hline
\end{tabular}

Tabel 2. Nyeri kepala ketika atau sesaat setelah bermain game komputer

\begin{tabular}{ccc}
\hline Nyeri Kepala & Frekuensi (N) & Persen (\%) \\
\hline Tidak & 6 & 12,0 \\
Ya & 44 & 88,0 \\
Total & 50 & 100,0 \\
\hline
\end{tabular}

Tabel 3. Cross tabulation dari durasi bermain game komputer dan tipe nyeri kepala

\begin{tabular}{|c|c|c|c|c|c|}
\hline & \multicolumn{3}{|c|}{ Gejala Nyeri Kepala Mengarah ke } & \multirow{2}{*}{ Total } \\
\hline & & Migraine & Tension-type & Tidak Nyeri & \\
\hline & 3-4 jam & 9 & 15 & 4 & $28(56 \%)$ \\
\hline Durasi Main & 4-5 jam & 1 & 2 & 0 & $3(6 \%)$ \\
\hline \multirow[t]{2}{*}{ Komputer } & 5-6 jam & 0 & 8 & 1 & $9(18 \%)$ \\
\hline & $>6$ jam & 4 & 5 & 1 & $10(20 \%)$ \\
\hline \multicolumn{2}{|c|}{ Total } & $14(28 \%)$ & $30(60 \%)$ & $6(12 \%)$ & $50(100 \%)$ \\
\hline
\end{tabular}

Berdasarkan saat bermain game komputer, pada sore-malam, sebanyak 13 orang memiliki gejala yang mengarah ke nyeri kepala tipe tensi dan 8 orang tipe migraine dari total 23 orang. Pada malamsubuh 14 orang tipe tensi dan 5 orang tipe 
migraine dari total 22 orang. Pada siangsore 2 orang gejalanya mengarah ke nyeri kepala tipe tensi dan 1 orang tipe migraine dari total 4 orang. Hanya 1 orang yang biasa bermain game komputer pada pagisiang hari (Tabel 4).

Tabel 4. Cross tabulation dari saat bermain game komputer dan tipe nyeri kepala

\begin{tabular}{cccccc}
\hline & \multicolumn{3}{c}{ Gejala Nyeri Kepala Mengarah ke } & \multirow{2}{*}{ Total } \\
\cline { 3 - 5 } & Migraine & Tension-type & Tidak Nyeri & \\
\hline \multirow{4}{*}{ Saat } & 0 & 1 & 0 & $1(2 \%)$ \\
& pagi-siang & 0 & 2 & 1 & $4(8 \%)$ \\
& siang-sore & 1 & 13 & 2 & $23(46 \%)$ \\
& sore-malam & 8 & 14 & 3 & $22(44 \%)$ \\
& malam-subuh & 5 & $30(60 \%)$ & $6(12 \%)$ & $50(100 \%)$ \\
\hline
\end{tabular}

\section{BAHASAN}

Penelitian ini menggunakan desain potong lintang yang bertujuan untuk mengetahui gambaran nyeri kepala pada mahasiswa pemain game komputer di Fakultas Kedokteran Universitas Sam Ratulangi angkatan 2012 dengan menggunakan kuesioner. Pada penelitian ini, subjek penelitian sebanyak 50 orang mahasiswa yang terdiri dari 41 mahasiswa laki-laki dan 9 mahasiswa perempuan. Dari 50 orang mahasiswa yang bermain game komputer $\geq 3$ jam, didapati 44 mahasiswa (88\%) mengalami nyeri kepala ketika atau sesaat setelah bermain game komputer. Pada penelitian Beck tahun 2010 yang mengacu dari National Institute of Occupational Safety and Health menunjukkan bahwa $90 \%$ orang yang menggunakan komputer lebih dari 3 jam mengalami nyeri kepala, mata lelah, dan nyeri punggung bawah. ${ }^{8}$

Berdasarkan hasil penelitian pada mahasiswa pemain game komputer ini, didapati $88 \%$ mengalami nyeri kepala ketika atau sesaat setelah bermain game komputer. Bagi mereka yang menggunakan komputer $>56$ jam/minggu, rasio prevalensi secara signifikan meningkat untuk nyeri leher atau nyeri bahu dan keduanya, dan juga untuk kelelahan mata. Sesuai dengan Tabel 3, gejala-gejala yang dialami paling banyak mengarah ke tipe tensi yaitu sebanyak 60\% dari 50 sampel. Penelitian oleh Madsen et al. ${ }^{4}$ mengemukakan bahwa posisi duduk yang tidak benar khususnya fleksi leher yang tidak benar dan sikap tubuh yang statis juga mempunyai hubungan yang bermakna dengan nyeri leher dan nyeri kepala. Kontraksi otot leher dan kepala yang berlebihan atau tegang menyebabkan input nosiseptif yang berkepanjangan sehingga terjadi sensitisasi sentral yang mempengaruhi regulasi dan mekanisme perifer. Hal tersebut menyebabkan peningkatan aktivitas otot terutama otot perikranial dan memicu pengeluaran neurotransmitter yang menyebabkan nyeri kepala. Selain itu, otototot leher berperan penting pada patogenesa nyeri kepala jenis migraine yang juga memfasilitasi sensitisasi sentral.

Untuk migraine, didapat $28 \%$ dari 50 responden. Penggunaan komputer dalam waktu yang lama dapat menyebabkan paparan cahaya yang berlebihan serta stress yang menjadi faktor risiko nyeri kepala migraine. Paparan cahaya yang berlebihan saat bermain komputer menuju ke retina yang mengaktivasi sekelompok sel retina. Sel-sel retina tersebut berfungsi sebagai pengontrol sleep-wakefulness. Dari sel-sel tersebut neurotransmitter diteruskan ke neuron-neuron yang diidentifikasi sebagai neuron pemicu migraine sesuai dengan penelitian yang dilakukan Noseda pada tahun 2010. Neuron-neuron tersebut teraktivasi ketika ada rangsangan cahaya dan tetap teraktivasi walau rangsangan cahaya disingkirkan, ini menjelaskan kenapa nyeri kepala masih terasa setelah 20-30 menit walaupun sudah berada di 
tempat gelap. ${ }^{10}$

Selain cahaya, beberapa stimuli juga berperan sebagai faktor risiko, diantaranya yaitu suara bising dan getaran. Berdasarkan hasil penelitian yang yang dilakukan Tso pada tahun 2014 menggunakan MRI, didapat bahwa penderita migraine memiliki konektivitas lebih besar pada korteks visual primer dan auditorial dengan dorsal Anterior Insula (dAI). Dorsal AI merupakan area yang berpengaruh pada respon kordinasi nosispetif dan stimuli baik dari luar maupun dalam tubuh. ${ }^{11}$

Berdasarkan Tabel 4, responden paling banyak bermain game pada waktu soremalam yakni sebanyak $46 \%$ dan kedua terbanyak yaitu pada waktu malam-subuh sebanyak 44\%. Penggunaan komputer pada malam hari dapat berakibat pada terganggunya waktu tidur. Kurang tidur menyebabkan tingginya sekresi protein p38, PKA, P2X3 yang mengaktivasi sistem saraf. Pada keadaan kurang tidur, protein pengaktivasi sistem saraf tersebut meningkat hingga sampai pada level yang dapat memicu nyeri kepala.

Derajat nyeri kepala ringan merupakan yang terbanyak dialami yakni sebanyak 56\% karena paling banyak responden mengisi 3-4 jam sebagai durasi waktu yang sering digunakan untuk bermain game. Berdasarkan penjelasan di atas, dapat diketahui gambaran nyeri kepala pada mahasiswa pemain game komputer.

\section{SIMPULAN}

Dari hasil penelitian dapat disimpulkan bahwa pada mahasiswa yang bermain game komputer derajat nyeri yang paling banyak dialami ialah ringan dan mengarah ke nyeri kepala tipe tensi. Jumlah mahasiswa pemain game komputer yang mengalami nyeri kepala lebih banyak daripada yang tidak mengalami nyeri kepala, tersering berusia 21 tahun dan berjenis kelamin lakilaki. Durasi bermain game komputer per hari paling sering 3-4 jam.

\section{DAFTAR PUSTAKA}

1. Hauser SL, Josephson SA, Longo DL, Fauci AS, Kasper DL. Harrison's
Neurology in Clinical Medicine (3rd ed). McGraw Hill Education, 2013; p. 51.

2. Ong BK. A Comparisson-based Study of Headache Diagnosis and Prevalence in Singapore. 2003. [cited 26 September 2015]. Available from: http://www.ncbi.nlm.nih.gov/pubmed ?term=prevalensitensiontypeheadache disingapore.htm.

3. Anderson P. Tension-Type Headaches Linked to Neck Weakness. Medscape Medical News. 2015. [cited 18 Oktober 2015]. Available from: http://www.medscape.com/viewarticl e/844414\#vp_1.

4. Madsen BK, Søgaard K, Andersen LL, Skotte JH, Jensen RH. Neck and Shoulder Muscle Strength in Patients with Tension-type Headache: A Casecontrol Study. Cephalalgia. 2015. Doi: 10.1177/0333102415576726.

5. Kinik ST, Alehan F, Erol I, Kanra AR. Obesity and Paediatric Migraine. International Headache Society. Cephalalgia. 2010;30:105.

6. Torsheim T, Eriksson L, Schnohr CW, HansenF, Bjarnason T, Välimaa R. Screen-Based Activities and Physical Complaints Among Adolescents from The Nordic Countries. BMC Public Health. 2010;10:324.

7. Hebert S, Beland R, Dionne O, Crete M, Lupien SJ. Physiological Stress Response to Video Game Playing: The Contribution of Built-in Music. Life Sciences. 2005;76:2371-80.

8. Beck M. Becoming a Squinter Nation. Wall St. Journal. 2010;2:5.

9. Kathiresan HN. Hubungan Penggunaan Media Elektronik Dengan Nyeri Kepala pada Mahasiswa Stambuk 2011 Fakultas Kedokteran Universitas Sumatera Utara [Tesis]. Medan: Universitas Sumatera Utara; 2014.

10. Noseda R, Kainz V, Jakubowski M, Gooley J, Saper C, Digre K, Burstein R. A Neural Mechanism for Exacerbation of Headache by Light. Nature Neuroscience. 2009;13:23945.

11. Palm P, Risberg EH, Mortimer M, Palmerud G, Toomingas A, Tornqvist EW. Computer Use, Neck 
Rori, Tumboimbela, Kembuan: Gambaran nyeri kepala...

and Upper Extremity Symptoms,

School Students. SJWEH suppl.

Eyestrain, and Headache among 2007;(3):33-41.

Female and Male Upper Secondary 